\title{
PENGARUH PENENTUAN LOKASI TERHADAP KESUKSESAN USAHA JASA BERSKALA MIKRO/KECIL
}

\author{
Wisnu Adhi Putra ${ }^{1}$, Nana Nawasiah ${ }^{2}$, Murti Widyaningsih ${ }^{3}$ \\ 1,2,3 Universitas Pancasila, Jakarta, Indonesia \\ Email: 2nananawasiah@univpancasila.ac.id ${ }^{*}$ )
}

\begin{abstract}
Business location is a place where companies produce goods or services that focus on the economy. The development of a company is determined by one important factor, namely location decision. The purpose of this study is to determine the effect of location decision (based on business environment conditions, infrastructure availability, and location costs) on business success. Data collection in this study was carried out through observation, interviews, and distributing questionnaires to several micro/small scale copy center business owners in Jagakarsa, South Jakarta. Analysis of the data in this study uses multiple linear regression analysis. This study provides results that the condition of the business environment, the availability of infrastructure, and location costs have a positive and significant effect both partially and simultaneously on business success. Therefore, as an effort to achieve and increase business success, business owners must consider the condition of the business environment, the availability of infrastructure, and location costs when determining/choosing a business location.
\end{abstract}

Keywords: location costs, business environmental conditions, availability of infrastructure, business success

\section{ABSTRAK}

Lokasi usaha adalah tempat perusahaan memproduksi barang atau jasa yang berfokus pada ekonomi. Perkembangan suatu perusahaan ditentukan oleh salah satu faktor penting yaitu penentuan lokasi. Tujuan dilakukannya penelitian ini yaitu untuk mengetahui pengaruh penentuan lokasi (ditinjau berdasarkan kondisi lingkungan bisnis, ketersediaan infrastruktur, dan biaya lokasi) terhadap kesuksesan usaha. Perolehan data pada penelitian ini dilakukan melalui observasi, wawancara, dan membagikan kuesioner kepada beberapa pemilik usaha fotokopi berskala mikro/kecil di Kecamatan Jagakarsa, Jakarta Selatan. Analisis data penelitian ini menggunakan analisis regresi linier berganda. Penelitian ini memberikan hasil bahwa kondisi lingkungan bisnis, ketersediaan infrastruktur, dan biaya lokasi berpengaruh positif dan signifikan baik secara parsial maupun simultan terhadap kesuksesan usaha. Maka, sebagai upaya pencapaian maupun peningkatan kesuksesan usaha, para pemilik usaha harus mempertimbangkan kondisi lingkungan bisnis, ketersediaan infrastruktur, dan biaya lokasi saat menentukan/memilih lokasi usaha.

Kata kunci: biaya lokasi, kondisi lingkungan bisnis, ketersediaan infrastruktur, kesuksesan usaha

\section{KETERANGAN ARTIKEL}

Riwayat Artikel: diterima: 26 Maret 2020; direvisi: 1 Juni 2020; disetujui: 16 Juni 2020

Klasifikasi JEL: D24

Cara Mensitasi: Putra, W.A., dkk. (2020). Pengaruh Penentuan Lokasi Terhadap Kesuksesan Usaha Jasa Berskala Mikro/Kecil. JIMFE (Jurnal Ilmiah Manajemen Fakultas Ekonomi), 6(1), 91-102. https://doi.org/10.34203/jimfe.v6i1.1893

Copyright@2020. JIMFE (Jurnal Manajemen Ilmiah Fakultas Ekonomi) Universitas Pakuan

\footnotetext{
${ }^{*}$ Corresponding author
} 


\section{PENDAHULUAN}

Persaingan antar perusahaan baik jasa maupun manufaktur semakin sulit pada saat ini, sehingga dibutuhkan adanya keunggulan bersaing bagi setiap perusahaan agar dapat menghasilkan profit dan memuaskan pelanggan. Keunggulan bersaing perusahaan didukung oleh salah satu faktor yaitu penentuan lokasi usaha yang tepat dan strategis.

Semua perusahaan, tak terkecuali skala mikro atau kecil, harus memilih lokasi usaha yang tepat. Hal ini bertujuan agar perusahaan tersebut unggul dan dapat mencapai kesuksesan usaha.

Terdapat salah satu fenomena mengenai lokasi usaha yaitu jarak antara tempat fotokopi satu dengan yang lainnya berdekatan. Biasanya, fenomena ini dapat ditemukan di sekitar sekolah dan kampus yang terdapat di daerah Kecamatan Jagakarsa, Jakarta Selatan. Apabila ditinjau berdasarkan kondisi lingkungan bisnisnya, peluang maupun ancaman dapat timbul apabila lokasi usaha berdekatan dengan pesaingnya. Sebagai contoh, kemungkinan besar pelanggan akan beralih dari tempat fotokopi dengan antrean yang panjang ke tempat fotokopi lain yang terdekat dengannya. Akan tetapi, tidak hanya kondisi lingkungan bisnis yang dipertimbangkan saat menentukan lokasi usaha jasa, ketersediaan infrastruktur dan biaya lokasi pun perlu ditinjau. Maka dari itu, tujuan perusahaan seperti kesuksesan usaha dapat tercapai jika dilakukannya penentuan lokasi dengan tepat. Berdasarkan fenomena yang diuraikan, usaha fotokopi menjadi fokus dalam penelitian ini.

Penelitian terkait penentuan/pemilihan lokasi telah dilakukan oleh para peneliti sebelumnya. Hasil penelitian yang dilakukan Fuad (2015) yaitu terdapat perubahan searah antara kedekatan infrastruktur, biaya lokasi, dan kondisi lingkungan bisnis dengan kesuksesan usaha. Fathoni (2016) memberikan hasil penelitian bahwa adanya pengaruh parsial pada lingkungan bisnis dan biaya lokasi terhadap tingkat penjualan, serta adanya pengaruh simultan pada lingkungan bisnis, biaya lokasi, dan infrastruktur terhadap tingkat penjualan.

Beberapa penelitian lain mengenai lokasi usaha jasa yaitu dari Hanggita (2018) bahwa lokasi usaha jasa mempertimbangkan faktor tenaga kerja, fasilitas, energi, akses, pasar, peraturan pemerintah, dan persaingan. Penelitian Iksyaniyah dan Soesatyo (2015) menyatakan lokasi usaha dan keberhasilan usaha memiliki pengaruh positif. Selain itu, pertimbangan aksesibilitas, tingkat keramaian, lingkungan, lalu lintas, dan strategi bersaing menjadi pertimbangan bagi para pemilik bisnis dalam menentukan lokasi usaha berdasarkan penelitian dari Rismalaningrum (2017). Sedangkan, penelitian terkait usaha jasa penginapan oleh dari Ali dan Simdani (2018) menyatakan bahwa secara parsial terdapat pengaruh positif antara lokasi dengan keputusan menginap.

Dalam menentukan lokasi industri, beberapa variabel yang berperan penting, yaitu lokasi, fasilitas, dan bahan baku (Octinanda dan Nazamuddin, 2016). Pemilihan lokasi industri juga memperhatikan utilitas, lahan, akses, risiko bencana, dan pengembangan kawasan (Rianto dan Santoso, 2018).

Uraian latar belakang dan hasil penelitian sebelumnya menjadi dasar bagi peneliti melakukan penelitian ini dengan tujuan untuk mengetahui pengaruh kondisi lingkungan bisnis, ketersediaan infrastruktur, dan biaya lokasi terhadap kesuksesan usaha. Pengaruh dilihat secara parsial dan simultan.

Penelitian ini diharapkan dapat bermanfaat secara teoritis yaitu menambah wawasan pembaca tentang strategi penentuan lokasi usaha sektor jasa, serta manfaat praktis yaitu menyampaikan pengetahuan kepada para pengusaha yang ingin menentukan lokasi usaha. 


\section{KAJIAN LITERATUR DAN PENGEMBANGAN HIPOTESIS}

Menurut Tjiptono (Maulana, 2018), tempat yang dijadikan perusahaan untuk menghasilkan produk (baik barang ataupun jasa) terkait bisnisnya disebut sebagai lokasi usaha. Berdasarkan Heizer dan Render (2016), besarnya biaya dan pendapatan bergantung dari strategi perusahaan dalam memilih lokasi. Apabila lokasi yang dipilih strategis, maka keuntungan juga dapat lebih maksimal.

Ukuran sukses dari Irawan dan Mulyadi (2016) yaitu jika terdapat pencapaian dari sasaran perusahaan. Sasaran tersebut dapat berupa pendapatan meningkat, produktivitas meningkat, citra baik, dan tingginya daya saing.

Banyak faktor lain untuk menilai suksesnya suatu usaha. Berdasarkan Fuad (2015), faktor-faktor tersebut seperti banyaknya pelanggan yang datang, laba bersih yang meningkat, dan waktu tercapainya break even point (BEP).

Usaha mikro, kecil, menengah (UMKM) dibagi berdasarkan ketentuan-ketentuan tertentu. Beberapa ketentuan terkait skala UMKM yaitu sebagai berikut.

Tabel 1. Skala UMKM (Usaha Mikro, Kecil, Menengah)

Berdasarkan Pasal 6 Undang-undang Nomor 20 Tahun 2008

\begin{tabular}{|c|c|c|c|}
\hline Skala Usaha & Aset Bersih & Omzet Tahunan & Keterangan \\
\hline Mikro & $\geq$ Rp50.000.000 & $\geq$ Rp300.000.000 & \multirow{3}{*}{$\begin{array}{l}\text { Aset bersih (tidak } \\
\text { termasuk tanah dan } \\
\text { bangunan) }\end{array}$} \\
\hline Kecil & $\begin{array}{l}\text { Rp50.000.000 s.d. } \\
\text { Rp500.000.000 }\end{array}$ & $\begin{array}{l}\text { Rp300.000.000 s.d. } \\
\text { Rp2.500.000.000 }\end{array}$ & \\
\hline Menengah & $\begin{array}{l}\text { Rp500.000.000 s.d. } \\
\text { Rp10.000.000.000 }\end{array}$ & $\begin{array}{c}\text { Rp2.500.000.000 s.d. } \\
\text { Rp50.000.000.000 }\end{array}$ & \\
\hline
\end{tabular}

Sumber: Saiman, 2014

Dalam strategi penentuan lokasi, usaha yang bergerak di bidang jasa dan manufaktur tentunya berbeda. Revenue dan konsumen menjadi hal yang penting bagi usaha jasa. Model regresi, pemeringkatan faktor, analisis lalu lintas, daya beli, demografi, sistem informasi geografis, dan metode center of gravity digunakan sebagai teknik untuk menentukan lokasi usaha jasa. Berbeda dengan usaha manufaktur dengan fokus kepada biaya. Usaha manufaktur menggunakan analisis cost-volume, diagram garis silang, pemeringkatan faktor, dan metode transportasi sebagai teknik dalam memilih lokasi yang strategis (Heizer dan Render, 2016).

Lokasi usaha pada dasarnya perlu ditentukan dengan pertimbangan berbagai macam hal. Menurut Tjiptono (Hidayat dan Zularni, 2014), beberapa pertimbangan tersebut seperti lokasi usaha yang dapat/mudah terlihat, kondisi lahan parkir, akses, traffic, kemungkinan perluasan, kebijakan pemerintah setempat, lingkungan, dan persaingan.

Penjelasan lebih lanjut mengenai pertimbangan penentuan lokasi usaha jasa dikemukakan oleh Krajewski, dkk. (2016). Pertama, jarak yang dekat antara lokasi usaha dengan pelanggan tentunya akan memudahkan pelanggan untuk datang ke lokasi usaha tersebut. Lokasi yang dekat dengan pasar dan perhitungan biaya transportasi menjadi pertimbangan kedua untuk meminimalisir biaya karena tingginya biaya ongkos kirim bahan baku. Ketiga, apabila lokasi usaha dekat dengan pesaing maka perlu dicermati karena hal ini dapat menjadi peluang ataupun ancaman bagi usaha yang dijalankan. Keempat, business owner mempertimbangkan faktor-faktor tertentu 
Wisnu Adhi Putra: Pengaruh Penentuan Lokasi ...

yang disesuaikan dengan kebutuhan usahanya.

Saat memilih lokasi usaha jasa, terdapat beberapa faktor pertimbangan yang utama. Menurut Chuong dan Stevenson (2014), faktor pertimbangan yang utama tersebut seperti lalu lintas, kenyamanan, tempat parkir, dan jarak dengan pasar.

Saiman (2014) menjabarkan enam faktor utama agar tepat dalam memilih lokasi. Pertama, jarak antara tempat usaha dengan sumber daya dekat. Kedua, pertimbangan pribadi pemilik usaha, seperti mengutamakan wilayah dengan biaya pekerja yang rendah. Ketiga, faktor keluarga seperti memilih lokasi usaha yang dekat dengan rumah. Keempat, konsumen dapat dengan mudah mengakses ke lokasi usaha. Kelima, pertimbangan lingkungan bisnis seperti jarak dengan pesaing, jenis usaha lain, pelanggan, dan supplier. Keenam, biaya dan tempat tersedia.

Dalam menentukan lokasi, biaya juga penting untuk dipertimbangkan. Biaya-biaya seperti untuk menggunakan/membeli suatu tempat dan mengubah tempat seperti biaya sewa, biaya tanah, biaya konstruksi, dan biaya renovasi termasuk ke dalam biaya lokasi (Gupta dan Starr, 2014).

Terdapat beberapa hal yang menjadi acuan dalam menentukan lokasi usaha jasa bagi para peneliti terdahulu. Acuan yang pertama yaitu kondisi lingkungan bisnis (Fuad, 2015) dengan pertimbangan kedekatan dengan konsumen (Krajewski, dkk., 2016), kedekatan dengan pesaing (Chuong dan Stevenson, 2014), dan kedekatan dengan usaha jasa lain (Saiman, 2014). Acuan yang kedua yaitu ketersediaan infrastruktur (Fathoni, 2016) dengan pertimbangan akses (Heizer dan Render, 2016), lahan parkir (Chuong dan Stevenson, 2014), dan ketersediaan listrik (Gupta dan Starr, 2014). Acuan yang ketiga yaitu biaya lokasi (Fathoni, 2016) dengan pertimbangan biaya sewa (Heizer dan Render, 2016), biaya renovasi (Gupta dan Starr, 2014), dan biaya insentif bangunan (Fathoni, 2016).
Penggunaan indikator akses pada variabel ketersediaan infrastruktur di penelitian ini menjadi pembeda dengan penelitian dari Fuad (2015). Uraian latar belakang, teori, serta penelitian terdahulu menjadi dasar pembentukan kerangka pemikiran dari penelitian ini sebagai berikut:

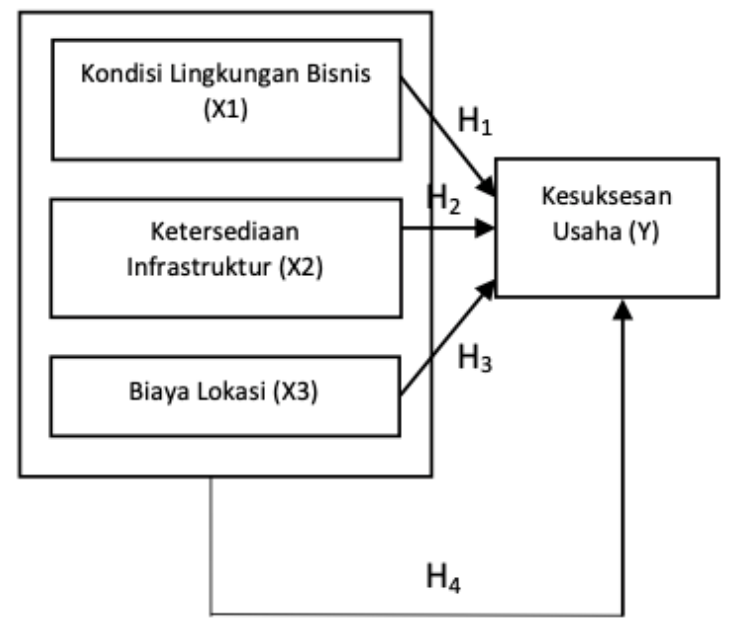

Gambar 1. Kerangka Pemikiran

Adapun hipotesis dari penelitian ini sebagai berikut:

$\mathrm{H}_{1}$ : Kondisi lingkungan bisnis secara parsial berpengaruh positif terhadap kesuksesan usaha.

$\mathrm{H}_{2}$ : Ketersediaan infrastruktur secara parsial berpengaruh positif terhadap kesuksesan usaha.

$\mathrm{H}_{3}$ : Biaya lokasi secara parsial berpengaruh positif terhadap kesuksesan usaha.

$\mathrm{H}_{4}$ : Kondisi lingkungan bisnis, ketersediaan infrastruktur, dan biaya lokasi secara simultan berpengaruh terhadap kesuksesan usaha.

\section{METODE PENELITIAN}

Untuk memperoleh data yang lebih valid, komprehensif, objektif, dan reliabel, maka digunakan metode penelitian kombinasi. Artinya, penelitian kuantitatif dan kualitatif digunakan sebagai metode penelitian ini.

Penelitian ini terdiri dari empat variabel yang terdiri dari tiga variabel independen dan satu variabel dependen. Variabel independen 
penelitian ini meliputi kondisi lingkungan bisnis $\left(X_{1}\right)$, ketersediaan infrastruktur $\left(X_{2}\right)$, dan biaya lokasi $\left(X_{3}\right)$. Adapun variabel dependennya yaitu kesuksesan usaha $(\mathrm{Y})$.

Populasi sebagai himpunan elemen dengan karakteristik identik yang menjadi sentral dalam penelitian. Sedangkan, kumpulan bagian dari populasi disebut sebagai sampel. Pada penelitian ini, terdapat 53 usaha fotokopi di Kecamatan Jagakarsa, Jakarta Selatan yang menjadi populasi penelitian. Sedangkan untuk sampel penelitian ini berjumlah 35 responden (pemilik usaha fotokopi di Kecamatan Jagakarsa, Jakarta Selatan) untuk memudahkan penelitian dan sumber daya serta didasari oleh teori dari Arifin (2011, p.224) bahwa apabila total anggota populasi sebesar 51-100, maka dapat digunakan sampel sebesar 50\%-60\%.

Data yang terdapat pada penelitian ini dikumpulkan melalui metode kuesioner, wawancara, observasi, dan studi kepustakaan. Kuesioner yang digunakan meliputi kuesioner terbuka dan kuesioner tertutup berskala likert dengan skala satu (1) hingga lima (5) yang artinya sangat tidak setuju hingga sangat setuju. Sebagai pelengkapnya, digunakan wawancara tidak terstruktur, observasi, dan studi kepustakaan.

\section{HASIL DAN PEMBAHASAN}

Kriteria Three-box Method oleh Ferdinand (dalam Fathoni, 2016:36) digunakan pada penelitian ini dengan rentang skor senilai 0,3 yang digunakan sebagai dasar penafsiran skor indeks sebagai berikut:

Tidak setuju: $0,10-0,40$

Netral: $0,41-0,70$

Setuju: $0,71-1,00$

Penafsiran Responden

Tabel 2. Penafsiran Responden (Pemilik Usaha Fotokopi) Terkait Kondisi Lingkungan Bisnis dalam Penentuan Lokasi Usaha Fotokopi

\begin{tabular}{lcccccc}
\hline \multicolumn{1}{c}{$\begin{array}{c}\text { Indikator Kondisi Lingkungan } \\
\text { Bisnis }\end{array}$} & $\mathbf{1}$ & $\mathbf{2}$ & $\mathbf{3}$ & $\mathbf{4}$ & $\mathbf{5}$ & \multirow{2}{*}{ Skor Indeks } \\
\cline { 2 - 6 } & $0 / 35$ & $0 / 35$ & $3 / 35$ & $15 / 35$ & $17 / 35$ & 0,88 \\
\hline Kedekatan dengan konsumen & $0 / 35$ & $2 / 35$ & $16 / 35$ & $13 / 35$ & $4 / 35$ & 0,71 \\
\hline Kedekatan dengan pesaing & $0 / 35$ & $0 / 35$ & $12 / 35$ & $14 / 35$ & $9 / 35$ & 0,78 \\
\hline Kedekatan dengan usaha jasa lain & 0 & & Rata-rata & $\mathbf{0 , 7 9}$
\end{tabular}

Tabel 3. Penafsiran Responden (Pemilik Usaha Fotokopi) Terkait Ketersediaan Infrastruktur dalam Penentuan Lokasi Usaha Fotokopi

\begin{tabular}{lcccccc}
\hline \multirow{2}{*}{$\begin{array}{c}\text { Indikator Kondisi Lingkungan } \\
\text { Bisnis }\end{array}$} & $\mathbf{1}$ & $\mathbf{2}$ & $\mathbf{3}$ & $\mathbf{4}$ & $\mathbf{5}$ & \multirow{2}{*}{ Skor Indeks } \\
\cline { 2 - 6 } & $0 / 35$ & $1 / 35$ & $4 / 35$ & $13 / 35$ & $17 / 35$ & 0,84 \\
\hline Akses & $0 / 35$ & $0 / 35$ & $4 / 35$ & $21 / 35$ & $10 / 35$ & 0,83 \\
\hline Lahan parkir & $0 / 35$ & $0 / 35$ & $9 / 35$ & $18 / 35$ & $8 / 35$ & 0,79 \\
\hline Ketersediaan listrik & & & \multicolumn{3}{c}{ Rata-rata } & $\mathbf{0 , 8 2}$ \\
\hline
\end{tabular}


Wisnu Adhi Putra: Pengaruh Penentuan Lokasi ...

Tabel 4. Penafsiran Responden (Pemilik Usaha Fotokopi) Terkait Biaya Lokasi dalam Penentuan Lokasi Usaha Fotokopi

\begin{tabular}{lcccccc}
\hline \multirow{2}{*}{$\begin{array}{c}\text { Indikator Kondisi Lingkungan } \\
\text { Bisnis }\end{array}$} & \multicolumn{4}{c}{ Skor } & \multirow{2}{*}{ Skor Indeks } \\
\cline { 2 - 6 } & $\mathbf{1}$ & $\mathbf{2}$ & $\mathbf{3}$ & $\mathbf{4}$ & $\mathbf{5}$ & \\
\hline Biaya sewa & $0 / 35$ & $3 / 35$ & $5 / 35$ & $17 / 35$ & $10 / 35$ & 0,79 \\
\hline Biaya renovasi & $0 / 35$ & $0 / 35$ & $9 / 35$ & $21 / 35$ & $5 / 35$ & 0,77 \\
\hline Biaya insentif bangunan & $0 / 35$ & $1 / 35$ & $8 / 35$ & $18 / 35$ & $8 / 35$ & 0,79 \\
\hline & & & & Rata-rata & $\mathbf{0 , 7 8}$ \\
\hline
\end{tabular}

Tabel 5. Penafsiran Responden (Pemilik Usaha Fotokopi) Terkait Kesuksesan Usaha Fotokopi

\begin{tabular}{lcccccc}
\multicolumn{1}{c}{$\begin{array}{c}\text { Indikator Kondisi Lingkungan } \\
\text { Bisnis }\end{array}$} & $\mathbf{1}$ & $\mathbf{2}$ & $\mathbf{3}$ & $\mathbf{4}$ & $\mathbf{5}$ & \multirow{2}{*}{ Skor Indeks } \\
\cline { 2 - 6 } & $0 / 35$ & $0 / 35$ & $13 / 35$ & $20 / 35$ & $2 / 35$ & 0,74 \\
\hline Tingkat kedatangan pelanggan & $0 / 35$ & $0 / 35$ & $11 / 35$ & $22 / 35$ & $2 / 35$ & 0,75 \\
\hline Pertumbuhan laba bersih & $0 / 35$ & $2 / 35$ & $15 / 35$ & $18 / 35$ & $0 / 35$ & 0,69 \\
\hline Waktu mencapai BEP & & & \multicolumn{3}{r}{ Rata-rata } & $\mathbf{0 , 7 3}$
\end{tabular}

Melalui hasil olah data pada tabel 2, kondisi lingkungan bisnis dipertimbangkan dalam penentuan lokasi usaha fotokopi. Terlihat dari skor indeks masing-masing indikator dan rata-rata skor indeks. Artinya, mereka setuju bahwa penentuan lokasi usaha perlu mempertimbangkan jarak dengan konsumen, pesaing, serta usaha jasa lain.

Data yang ditafsirkan melalui tabel 3 memberikan hasil bahwa ketersediaan infrastruktur dipertimbangkan saat menentukan lokasi usaha fotokopi. Dengan kata lain, responden setuju bahwa hal-hal seperti akses, lahan parkir, dan ketersediaan listrik perlu dipertimbangkan saat memilih lokasi usaha fotokopi.

Biaya lokasi juga dipertimbangkan saat memilih lokasi usaha fotokopi berdasarkan tabel 4. Responden setuju bahwa mereka memperhitungkan biaya sewa, renovasi, dan insentif bangunan saat memilih lokasi.

Tabel 5 menunjukkan responden setuju bahwa terdapat peningkatan pelanggan dan pertumbuhan laba bersih pada usaha jasa fotokopi yang dimilikinya. Sedangkan, responden beranggapan netral mengenai waktu untuk mencapai BEP (Break Even Point). Secara keseluruhan, responden setuju bahwa usaha jasa fotokopi yang dijalankan sukses atau sesuai target.
Melalui wawancara yang dilakukan peneliti, responden menjelaskan beberapa hal mengenai usaha fotokopi yang dijalankannya. Terkait jumlah pelanggan, biasanya pada waktu tertentu seperti ajaran baru sekolah dan saat menjelang atau sedang berjalannya ujian di kampus, terjadi peningkatan pelanggan yang cukup berarti. Seiring peningkatan pelanggan pada waktu tertentu, peningkatan laba bersih pun terjadi. Sedangkan, untuk waktu mencapai BEP (break even point) dinilai cukup lama karena butuh waktu sekitar satu hingga tiga tahun.

\section{Uji Validitas dan Reliabilitas}

Ukuran pernyataan pada kuesioner penelitian dikatakan valid jika $r_{\text {tabel }}$ lebih kecil dari $r_{\text {hitung }}$ (Wati, 2018). Uji validitas yang dilakukan memberikan hasil bahwa seluruh pernyataan pada variabel $X_{1}$ valid karena $r_{\text {tabel }}(0,334)$ lebih kecil dari $r_{\text {hitung }} X_{1.1}(0,752), \quad X_{1.2}(0,733)$, $\mathrm{x}_{1.3}(0,796)$. Setiap pertanyaan pada variabel $X_{2}$, $X_{3}$, dan $Y$ pun valid karena $r_{\text {tabel }}(0,334)$ lebih kecil dari $r_{\text {hitung }} X_{2.1}(0,859), \quad X_{2.2}(0,678)$, $X_{2.3}(0,751), X_{3.1}(0,848), X_{3.2}(0,593), X_{3.3}(0,806)$, $Y_{1.1}(0,741), Y_{1.2}(0,779), Y_{1.3}(0,781)$.

Dalam menguji reliabilitas kuesioner, penelitian ini didasari teori bahwa apabila Cronbach's Alpha di atas 0,60 maka kuesioner dinilai reliabel (Wati, 2018, p.108). Seluruh 
Cronbach's Alpha pada penelitian ini di atas 0,60 untuk $X_{1}(0,630), X_{2}(0,648), X_{3}(0,625)$, dan $\mathrm{Y}(0,649)$ yang artinya kuesioner penelitian sudah reliabel.

\section{Uji Normalitas}

Untuk mengetahui asumsi normalitas terpenuhi pada model regresi, penelitian ini menggunakan grafik Normal P-P Plot. Berdasarkan grafik dapat dinyatakan bahwa data berdistribusi normal karena data tidak menyebar jauh dari garis diagonal.

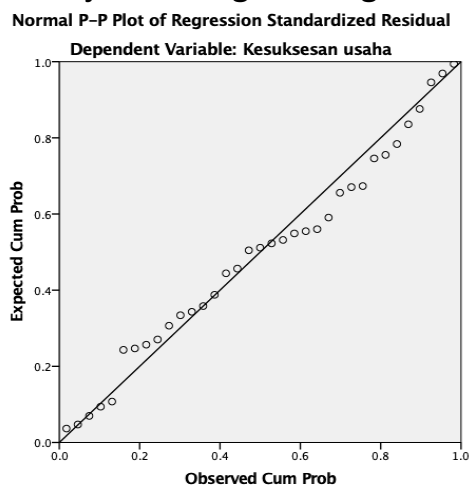

Gambar 2. Hasil Uji Normalitas

\section{Uji Multikolinearitas}

Nilai Tolerance pada masing-masing variabel independen lebih dari 0,10 dan nilai VIF kurang dari 10. Maka, di antara variabel independen pada model regresi penelitian ini tidak terjadi gejala multikolinearitas.

Tabel 6. Hasil Uji Multikolinearitas

\begin{tabular}{|c|c|c|c|}
\hline \multicolumn{4}{|c|}{ Coefficients $^{a}$} \\
\hline \multirow{2}{*}{\multicolumn{2}{|c|}{ Model }} & \multicolumn{2}{|c|}{ Collinearity Statistics } \\
\hline & & Tolerance & VIF \\
\hline \multirow[t]{5}{*}{1} & (Constant) & & \\
\hline & Kondisi & 876 & 1,142 \\
\hline & Lingkungan Bisnis & & \\
\hline & $\begin{array}{l}\text { Ketersediaan } \\
\text { Infrastruktur }\end{array}$ & 852 & 1,173 \\
\hline & Biaya Lokasi & ,858 & 1,165 \\
\hline
\end{tabular}

a. Dependent Variable: Kesuksesan Usaha

Sumber: Data primer yang diolah, 2019

\section{Uji Heteroskedastisitas}

Pengujian heteroskedastisitas penelitian ini menggunakan grafik Scatterplot. Dilihat dari grafik dapat dinyatakan bahwa tidak ada heteroskedastisitas pada model regresi penelitian ini, terbukti dari titik-titik yang tersebar tidak beraturan.

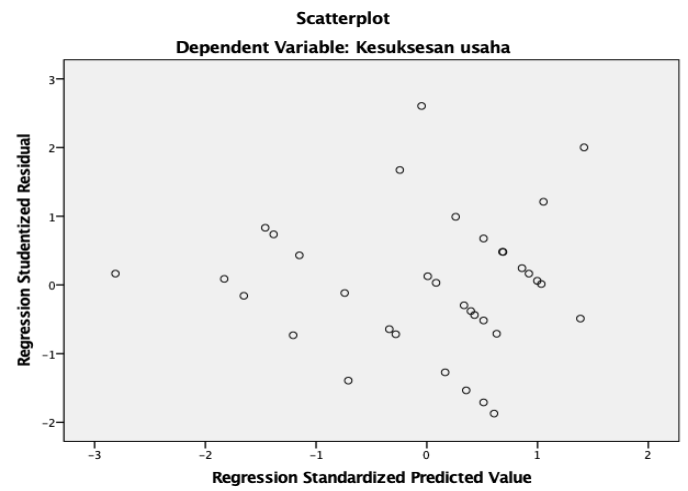

Gambar 3. Hasil Uji Heteroskedastisitas

\section{Uji Autokorelasi}

Berdasarkan Tabel 7, nilai dw sebesar 2,166. Nilai du sebesar 1,650 diperoleh berdasarkan $\mathrm{n}=35, \mathrm{k}=3$, (df = n-k-1). Maka, du $(1,650)<$ $\mathrm{dw}(2,166)<4-\mathrm{du}(2,350)$, artinya tidak terjadi autokorelasi.

Tabel 7. Hasil Uji Autokorelasi

\begin{tabular}{ccc}
\hline \multicolumn{3}{c}{ Model Summary $^{\boldsymbol{b}}$} \\
\hline Model & $\mathbf{R}$ & Durbin-Watson $^{-}$ \\
\hline 1 &, 794 & 2,166
\end{tabular}

a. Predictors (Constant): Biaya lokasi, kondisi lingkungan bisnis, ketersediaan infrastruktur b. Dependent Variable: Kesuksesan usaha Sumber: Data primer yang diolah, 2019

\section{Analisis Regresi Linier Berganda}

Regresi linier berganda sebagai hasil olah data pada penelitian ini memiliki persamaan berikut:

$$
Y=0,402+0,269 X_{1}+0,350 X_{2}+0,249 X_{3} \text { (1) }
$$

Nilai 0,402 merupakan konstanta. Artinya, variabel kesuksesan usaha $(Y)$ bernilai 0,402 jika nilai ketiga variabel independennya yang meliputi kondisi lingkungan bisnis $\left(\mathrm{X}_{1}\right)$, 
ketersediaan infrastruktur $\left(X_{2}\right)$, dan biaya lokasi $\left(\mathrm{X}_{3}\right)$ yaitu nol.

Nilai 0,269 merupakan koefisien regresi variabel kondisi lingkungan bisnis $\left(\mathrm{X}_{1}\right)$. Artinya, akan terjadi peningkatan sebesar 0,269 pada variabel dependen yaitu kesuksesan usaha $(Y)$ apabila variabel kondisi lingkungan bisnis $\left(X_{1}\right)$ mengalami peningkatan satu satuan dengan anggapan variabel $X_{2}$ dan $X_{3}$ bernilai nol.

Nilai 0,350 merupakan koefisien regresi variabel ketersediaan infrastruktur $\left(X_{2}\right)$. Artinya, akan terjadi peningkatan sebesar 0,350 pada variabel dependen yaitu kesuksesan usaha (Y) apabila variabel ketersediaan infrastruktur $\left(X_{2}\right)$ mengalami peningkatan satu satuan dengan anggapan variabel $X_{1}$ dan $X_{3}$ bernilai nol.

Nilai 0,249 merupakan koefisien regresi variabel biaya lokasi $\left(X_{3}\right)$. Artinya, akan terjadi peningkatan sebesar 0,249 pada variabel dependen yaitu kesuksesan usaha $(Y)$ apabila variabel biaya lokasi $\left(X_{3}\right)$ mengalami peningkatan satu satuan dengan anggapan variabel $X_{1}$ dan $X_{2}$ bernilai nol.

Tabel 8. Hasil Uji Analisis Regresi Linier

Berganda

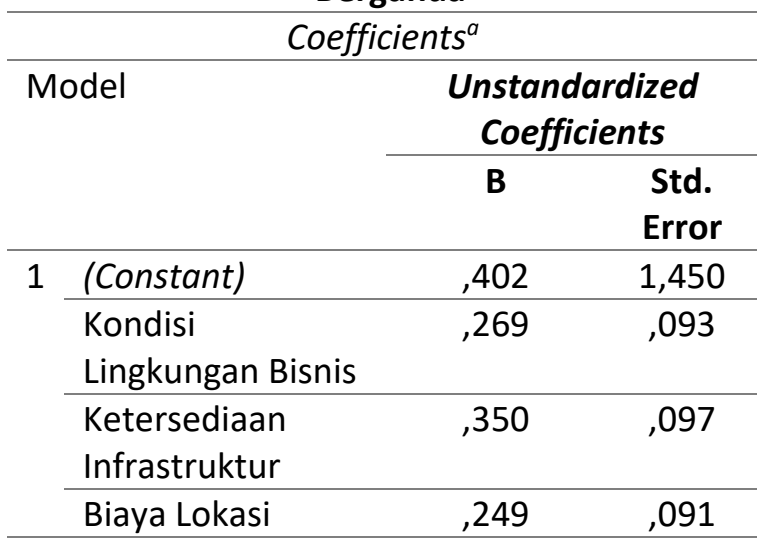

a. Dependent Variable: Kesuksesan Usaha

Sumber: Data primer yang diolah, 2019

\section{Koefisien Determinasi}

Pengujian koefisien determinasi memberikan hasil bahwa ketiga variabel independen penelitian ini yaitu kondisi lingkungan bisnis, ketersediaan infrastruktur, dan biaya lokasi mempengaruhi variabel kesuksesan usaha sebesar $59,5 \%$, sisanya $40,5 \%$ dijelaskan oleh variabel lain yang tidak diteliti pada penelitian ini. Persentase $59,5 \%$ diperoleh dari nilai Adjusted R Square.

Tabel 9. Hasil Uji Koefisien Determinasi

\begin{tabular}{lccc}
\hline \multicolumn{4}{c}{ Model Summary $^{\mathbf{b}}$} \\
\hline Model & R & R Square & $\begin{array}{c}\text { Adjusted } \\
\text { R Square }\end{array}$ \\
\hline 1 &, 794 &, 630 &, 595 \\
\hline $\begin{array}{l}\text { a. Predictors (Constant): Biaya lokasi, kondisi } \\
\text { lingkungan bisnis, ketersediaan infrastruktur }\end{array}$ \\
\hline \multicolumn{3}{l}{ b. Dependent Variable: Kesuksesan usaha } \\
\hline
\end{tabular}

Sumber: Data primer yang diolah, 2019

\section{Uji t}

Nilai $t_{\text {tabel }}=(\alpha / 2 ; n-k-1)$, jika $\alpha=0,05, n=35$, dan $k=3$, maka tabel $(0,025 ; 31)=2,040$. Uji parsial (t) pada penelitian ini memberikan hasil: Pertama, secara parsial, variabel kondisi lingkungan bisnis berpengaruh positif dan signifikan terhadap kesuksesan usaha. Hasil ini didasari oleh nilai $t_{\text {tabel }}(2,040)$ yang lebih kecil dari thitung $(2,886)$, serta probabilitas signifikansi $(0,007)$ kurang dari 0,05. Kedua, secara parsial, variabel ketersediaan infrastruktur berpengaruh positif dan signifikan terhadap kesuksesan usaha. Hasil ini didasari oleh nilai $t_{\text {tabel }}(2,040)$ yang lebih kecil dari thitung $(3,590)$, serta probabilitas signifikansi $(0,001)$ kurang dari 0,05. Ketiga, secara parsial, variabel biaya lokasi berpengaruh positif dan signifikan terhadap kesuksesan usaha. Hasil ini didasari oleh nilai $t_{\text {tabel }}(2,040)$ yang lebih kecil dari $t_{\text {hitung }}(2,736)$, serta probabilitas signifikansi $(0,010)$ kurang dari 0,05 . 
Tabel 10. Hasil Uji t

\begin{tabular}{|c|c|c|c|}
\hline \multicolumn{4}{|c|}{ Coefficients $^{a}$} \\
\hline \multirow{2}{*}{\multicolumn{2}{|c|}{ Model }} & \multicolumn{2}{|c|}{$\begin{array}{l}\text { Unstandardized } \\
\text { Coefficients }\end{array}$} \\
\hline & & B & $\begin{array}{l}\text { Std. } \\
\text { Error }\end{array}$ \\
\hline \multirow[t]{4}{*}{1} & (Constant) & 278 & ,783 \\
\hline & $\begin{array}{l}\text { Kondisi } \\
\text { Lingkungan Bisnis }\end{array}$ & 2,886 & 007 \\
\hline & $\begin{array}{l}\text { Ketersediaan } \\
\text { Infrastruktur }\end{array}$ & 3,590 & ,001 \\
\hline & Biaya Lokasi & 2,736 & ,010 \\
\hline
\end{tabular}

a. Dependent Variable: Kesuksesan Usaha

Sumber: Data primer yang diolah, 2019

\section{Uji F}

Uji simultan (F) memberikan hasil bahwa ketiga variabel independen (kondisi lingkungan bisnis, ketersediaan infrastruktur, dan biaya lokasi) secara simultan berpengaruh signifikan terhadap variabel dependen (kesuksesan usaha). Hasil ini didasari oleh nilai $F_{\text {hitung }}$ sebesar 17,619 yang lebih besar dari $F_{\text {tabel }}$ yaitu 2,90 , serta nilai signifikansi 0,000 yang kurang dari 0,05 .

Tabel 11. Hasil Uji F

\begin{tabular}{|c|c|c|c|c|c|c|}
\hline \multicolumn{7}{|c|}{ ANOVA $^{a}$} \\
\hline \multicolumn{2}{|r|}{ Model } & $\begin{array}{l}\text { Sum of } \\
\text { Squares }\end{array}$ & df & $\begin{array}{l}\text { Mean } \\
\text { Square }\end{array}$ & $\mathbf{F}$ & Sig. \\
\hline \multirow[t]{3}{*}{1} & Regression & 38,792 & 3 & 12,931 & 17,619 &, $000^{b}$ \\
\hline & Residual & 22,751 & 31 & ,734 & & \\
\hline & Total & 61,543 & 34 & & & \\
\hline \multicolumn{7}{|c|}{ a. Dependent Variable: Kesuksesan Usaha } \\
\hline & $\begin{array}{l}\text { Predictors } \\
\text { rastruktur }\end{array}$ & iaya lokasi & ndisi & gkungan & snis, & sediaan \\
\hline
\end{tabular}

Sumber: Data primer yang diolah, 2019

\section{Pembahasan}

Pengaruh Kondisi Lingkungan Bisnis terhadap Kesuksesan Usaha

Pembuktian hipotesis secara parsial memberikan hasil bahwa kondisi lingkungan bisnis $\left(X_{1}\right)$ berpengaruh positif dan signifikan terhadap kesuksesan usaha $(\mathrm{Y})$, berdasarkan $t_{\text {tabel }}(2,040)$ yang lebih kecil dari $t_{\text {hitung }}(2,886)$ serta signifikansi $(0,007)$ yang kurang dari 0,05 . Besarnya pengaruh $X_{1}$ terhadap $Y$ sebesar 0,269, memiliki arti bahwa terjadi peningkatan sebesar 0,269 pada variabel dependen yaitu kesuksesan usaha (Y) apabila variabel kondisi lingkungan bisnis $\left(X_{1}\right)$ mengalami peningkatan satu satuan dengan anggapan variabel $X_{2}$ dan $X_{3}$ bernilai nol.

Penelitian yang dilakukan ini memberikan hasil seperti penelitian yang dilakukan oleh Fuad (2015) dan Fathoni
(2016). Bahwa, setiap perubahan pada variabel kondisi lingkungan bisnis memberikan perubahan yang sejalan dengan variabel kesuksesan usaha.

Lokasi yang dekat jaraknya dengan pelanggan, pesaing, dan usaha jasa lain ternyata dipertimbangkan dalam menentukan lokasi usaha jasa dengan tujuan pencapaian kesuksesan usaha, terutama dalam hal kondisi lingkungan bisnis. Pada dasarnya, pelanggan akan mencari lokasi usaha yang lebih dekat dengannya. Bagi pemilik usaha, tentunya hal ini dapat menjadi peluang memilih lokasi usaha yang dekat dengan pesaing apabila memiliki pelayanan yang lebih cepat, lebih baik, dan memudahkan pelanggan. Contohnya, panjangnya antrean dari usaha pesaing membuat pelanggan akan berpindah ke tempat usaha lain yang terdekat dan 
pelanggan akan mendatangi lokasi usaha yang terdekat dengan posisinya saat ini. Peluang ini tentunya dapat meningkatkan jumlah pelanggan yang datang dan laba bagi pemilik usaha.

\section{Pengaruh Ketersediaan Infrastruktur terhadap Kesuksesan Usaha}

Hasil pengujian hipotesis parsial menghasilkan bahwa ketersediaan infrastruktur $\left(X_{2}\right)$ berpengaruh positif dan signifikan terhadap kesuksesan usaha (Y), berdasarkan $t_{\text {tabel }}(2,040)$ yang lebih kecil dari $t_{\text {hitung }}(3,590)$ serta signifikansi $(0,001)$ yang kurang dari 0,05 . Besarnya pengaruh $X_{2}$ terhadap $Y$ sebesar 0,350 yang berarti terjadi peningkatan sebesar 0,350 pada variabel dependen yaitu kesuksesan usaha $(Y)$ apabila variabel ketersediaan infrastruktur $\left(X_{2}\right)$ mengalami peningkatan satu satuan dengan anggapan variabel $X_{1}$ dan $X_{3}$ memiliki nilai nol.

Terdapat kesesuaian antara hasil dari penelitian ini dengan penelitian sebelumnya. Fuad (2015) memberikan hasil penelitian bahwa variabel ketersediaan infrastruktur memiliki pengaruh yang sejalan terhadap variabel kesuksesan usaha.

Sebagai variabel dengan pengaruh yang paling kuat pada penelitian ini, hal-hal seperti akses, lahan parkir, dan ketersediaan listrik tentunya sangat dipertimbangkan untuk variabel ketersediaan infrastruktur agar usaha yang dijalankan dapat sukses. Pelanggan pastinya butuh lokasi usaha yang mudah untuk diakses, baik menggunakan kendaraan umum, kendaraan roda dua atau empat, maupun berjalan kaki. Cukup luasnya tempat parkir kendaraan sangat dibutuhkan bagi pelanggan yang menggunakan kendaraannya untuk datang ke lokasi usaha, sangat dirugikan apabila pelanggan tidak jadi datang hanya karena tidak ada atau tidak cukupnya tempat parkir. Hal utama yaitu listrik, karena usaha fotokopi menggunakan mesin dalam mengoperasikan bisnis sehari-harinya.

\section{Pengaruh Biaya Lokasi terhadap Kesuksesan Usaha}

Hasil pengujian hipotesis parsial menghasilkan bahwa biaya lokasi $\left(X_{3}\right)$ berpengaruh positif dan signifikan terhadap kesuksesan usaha $(\mathrm{Y})$, berdasarkan $t_{\text {tabel }}(2,040)$ yang lebih kecil dari $t_{\text {hitung }}(2,736)$ serta signifikansi $(0,010)$ yang kurang dari 0,05 . Besarnya pengaruh $X_{3}$ terhadap $Y$ sebesar 0,249 yang berarti terjadi peningkatan sebesar 0,249 pada variabel dependen yaitu kesuksesan usaha $(Y)$ apabila variabel biaya lokasi $\left(X_{3}\right)$ mengalami peningkatan satu satuan dengan anggapan variabel $X_{1}$ dan $X_{2}$ memiliki nilai nol.

Penelitian yang dilakukan Fathoni (2016) dan Fuad (2015) memiliki hasil yang sesuai dengan hasil penelitian ini. Bahwa, variabel independen biaya lokasi dan variabel dependen kesuksesan usaha memiliki perubahan yang searah.

Hasil penelitian menunjukkan biaya lokasi sebagai variabel dengan pengaruh yang paling lemah dibandingkan dengan variabel lainnya, yang dapat dilihat dari koefisien regresi. Meski demikian, pertimbangan biaya saat memilih lokasi perlu dilakukan karena biaya sewa dan renovasi cukup besar nominalnya, dan sangat dirugikan apabila berpindah ke lokasi lain atau mengalami kerugian saat menjalankan usahanya yang disebabkan oleh kesalahan dalam memilih lokasi yang sesuai dengan kebutuhan usaha. Hal ini tentunya berdampak pada lamanya untuk mencapai titik impas usaha.

\section{Pengaruh Kondisi Lingkungan Bisnis, Ketersediaan Infrastruktur, dan Biaya Lokasi terhadap Kesuksesan Usaha \\ Hasil pengujian hipotesis secara} simultan yaitu ketiga variabel independen (kondisi lingkungan bisnis, ketersediaan infrastruktur, dan biaya lokasi) secara signifikan berpengaruh terhadap kesuksesan usaha. Hasil ini didasari oleh nilai $F_{\text {tabel }}(2,90)$ yang lebih kecil dari $F_{\text {hitung }}(17,619)$ serta signifikansi $(0,000)$ yang kurang dari 0,05 . Secara simultan, ketiga variabel independen 
ini berpengaruh 59,5\% terhadap variabel dependennya (kesuksesan usaha), dan 40,5\% sisanya dijelaskan oleh variabel-variabel yang tidak diteliti dalam penelitian ini.

\section{PENUTUP}

Peneliti mengambil poin penting dari seluruh hasil penelitian ini. Baik secara parsial dan simultan, terdapat pengaruh yang searah antara variabel independen (kondisi lingkungan bisnis, ketersediaan infrastruktur, dan biaya lokasi) terhadap variabel independen (kesuksesan usaha). Maka implikasinya yaitu, perlu bagi pemilik usaha untuk melihat kondisi lingkungan bisnis, ketersediaan infrastruktur, dan biaya lokasi sebagai pertimbangan memilih lokasi usaha, sebagai upaya mencapai usaha yang sukses.

Adapun beberapa saran dari peneliti untuk para pemilik usaha berdasarkan hasil penelitian ini. Hal-hal yang berhubungan dengan kondisi lingkungan bisnis meliputi jarak lokasi usaha dengan pesaing, pelanggan, dan usaha jasa lain sebaiknya diperhatikan, karena untuk dapat sukses yang dituju yaitu jumlah pelanggan meningkat dan pendapatan usaha juga meningkat. Selain itu, hal-hal terkait operasional sehari-hari suatu usaha yaitu ketersediaan infrastruktur, seperti akses yang mudah, cukup luasnya tempat parkir, dan tersedianya listrik sangat penting untuk dipertimbangkan. Terakhir, biaya-biaya untuk sewa, renovasi, dan insentif bangunan pun diperhitungkan dan pilih biaya yang ideal sesuai dengan jenis usaha yang dimiliki, karena biaya juga menentukan lamanya usaha tersebut mencapai titik impas usaha.

Saran yang kedua untuk penelitian selanjutnya. Diharapkan penelitian berikutnya yang terkait dengan strategi penentuan lokasi dapat menggunakan variabel, indikator, ataupun objek penelitian yang berbeda agar penelitian terkait penentuan lokasi dapat terus berkembang.

\section{REFERENSI}

Ali, S.K. dan Simdani D.L. (2018). Analisa Pengaruh Lokasi dan Servicescape Terhadap Keputusan Menginap Konsumen Pohon Inn Hotel. Jurnal Hospitality dan Manajemen Jasa, 6(1), 104-113.

Arifin, Z. (2011). Penelitian Pendidikan Metode dan Paradigma Baru. Bandung: Remaja Rosdakarya.

Chuong, S.C. dan Stevenson, W.J. (2014). Manajemen Operasi: Perspektif Asia. Edisi Kesembilan. Jakarta: Salemba Empat.

Fadhiliya, L., dkk. (2014). Analisis Faktor-faktor yang Mempengaruhi Keberhasilan Berwirausaha pada Alumni SMK di Kabupaten Purworejo. Jurnal Pendidikan Insan Mandiri, 1(2).

Fathoni, A. (2016). Analisa Faktor-faktor yang Mempengaruhi Pemilihan Lokasi Terhadap Tingkat Penjualan Usaha Jasa Mikro di Kabupaten Lamongan. JPIM (Jurnal Penelitian IImu Manajemen), 1(1), 22-33. http://dx.doi.org/10.30736\%2Fjpim.v1i1 .3.

Fuad, E.N. (2015). Pengaruh Pemilihan Lokasi Terhadap Kesuksesan Usaha Berskala Mikro / Kecil di Komplek Shopping Centre Jepara. Media Ekonomi dan Manajemen, 30(1), 56-67. http://dx.doi.org/10.24856.v30i1.234.

Gupta, S. dan Starr, M. (2014). Production and Operations Management Systems. Boca Raton: CRC Press.

Hanggita, A.T. (2018). Analisis Faktor Pemilihan Lokasi Usaha Jasa pada UMKM di Kecamatan Paciran. Manajemen Bisnis, 8(2), 167-176. http://doi.org/10.22219/jmb.v8i2.7069.

Heizer, J. dan Render, B. (2016). Operations Management: Sustainability and Supply Chain Management. Edisi Keduabelas. London: Pearson. 
Hidayat, R.T. dan Zularni, S. (2014). Pengaruh Lokasi Usaha pada Volume Penjualan (Survei pada Restoran Kecil di Lingkungan Universitas Riau). Jurnal Ilmiah Akuntansi dan Bisnis, 9(2), 92100.

Iksyaniyah, N. dan Soesatyo, Y. (2015). Pengaruh Lokasi Usaha terhadap Keberhasilan Usaha Pedagang Kaki Lima di Pasar Baru Krian Sidoarjo. Jurnal Pendidikan Ekonomi (JUPE), 3(3).

Irawan, A. dan Mulyadi, H. (2016). Pengaruh Keterampilan Wirausaha terhadap Keberhasilan Usaha. Journal of Business Management Education (JBME), 1(1), 213-223. http://doi.org/10.17509/jbME.v1i1.229 0 .

Kamarullah, R. (2017). Pemilihan Lokasi Strategis Usaha Toko Peralatan Listrik Berdasarkan Karakteristik dan Pola Sebarannya di Kabupaten Bantul. Jurnal Bumi Indonesia, 6(3), 1-20.

Krajewski, L.J., dkk. (2016). Operations Management: Processes and Supply Chains. Edisi Kesebelas. United States: Prentice Hall.

Rismalaningrum, I. (2017). Faktor-faktor Pertimbangan Pebisnis dalam Pemilihan
Lokasi Usaha Batik. Skripsi. Universitas Muhammadiyah Yogyakarta.

Maulana, Y.S. (2018). Analisis Faktor-faktor yang Mempengaruhi Pemilihan Lokasi Pabrik PT Sung Chang Indonesia Cabang Kota Banjar. Jurnal IImiah ADBIS (Administrasi Bisnis), 2(2), 211-221.

Nuritha, I., dkk. (2013). Identifikasi Pengaruh Lokasi Usaha Terhadap Tingkat Keberhasilan Usaha Minimarket Waralaba di Kabupaten Jember dengan Sistem Informasi Geografis. Jurnal Sainstek, I(1), 825-835.

Octiananda, C.T. dan Nazamuddin. (2016). Analisis Penentuan Lokasi: Studi Kasus Industri Rumah Tangga (Home Industry) di Wilayah Kota Banda Aceh. Jurnal Ilmiah Mahasiswa Ekonomi Pembangunan, 1(2), 438-445.

Rianto, I.B. \& Santoso, E.B. (2018). Penentuan Lokasi Kawasan Industri Tekstil Terpadu di Kabupaten Majalengka. Jurnal Teknik ITS, 7(1), 19-23. http://doi.org/10.12962/J23373539.v7i 1.28970 .

Saiman, L. (2014). Kewirausahaan: Teori, Praktik, dan Kasus-kasus. Edisi Kedua. Jakarta: Salemba Empat. 